\title{
PŘÍSPĚVEK K POZNÁNÍ HISTORIE ČESKÉHO EKONOMICKÉHO MYŠLENÍ
}

\section{Zuzana Džbánkováa}

\section{Antonie Doležalová: A History of Czech Economic Thought}

Londýn: Routledge, 2018. 1. vydání, 194 stran. ISBN 978-1-138-91416-2.

Ekonomické myšlení se vždy vyvíjelo v těsné vazbě na rozvoj společenských a hospodářských poměrů $\mathrm{v}$ jednotlivých zemích. Vznik českého ekonomického myšlení (ČEM) bývá obvykle $v$ české historiografii spojován s přednáškami prvních českých profesorů národního hospodářství v českém jazyce po rozdělení Karlo-Ferdinandovy univerzity na českou a německou větev v druhé polovině 19. století. Myslitelé, kteří se zabývají hospodářskou problematikou před rozdělením univerzity, jsou obvykle nazýváni předchůdci ČEM. Přičemž od počátku 20. století využívaly studie zabývající se ČEM tzv. teritoriální definici, podle které jsou k české tradici přiřazeni autoři působící $\mathrm{v}$ české části habsburské monarchie bez ohledu na národnost, nebo zda psali česky nebo německy. Po roce 1990 mezi ekonomy i historiky zájem o ČEM roste a jeho povaha se stává předmětem diskusí. Vysoce oceňovanými odborníky v oblasti historie ČEM byli prof. F. Vencovský a prof. M. Sojka. Mezi dalšími odborníky v oboru je třeba zmínit K. Půlpána, J. Havla, I. Bažantovou nebo J. Koderovou. Problematikou výuky národního hospodářství v dějinách českých zemí se zabývá dlouhodobě J. Krameš. ČEM je spjato s Českou ekonomickou společností (ČSE) a řada problémů byla řešena v rámci studií Národohospodářského ústavu Josefa Hlávky ${ }^{1}$ Podrobnější výčet vědců, kteří zprostředkovávají dobu českých národohospodářů a formování ČEM, rozsah recenze neumožňuje, avšak není možné nezmínit napřr. V. Jurečku, M. Šmejkala, E. Kubů, D. Jančíka, O. Králíka, O. Lišku a mnoho dalších. Nelze dále opomenout př́ínos F. Seidla, jenž významně přispěl zpř́stupnění starých spisů v rámci projektu ,Zlatý fond českého

a Vysoká škola ekonomická v Praze, Fakulta podnikohospodářská

E-mail: zuzana.dzbankova@vse.cz

1 Dostupné z: https://www.hlavkovanadace.cz/vydane_publikace.php 
ekonomického myšlení“. Vytvoření jeho elektronické podoby Bibliotheca Economica je spojeno se jménem A. Doležalové2.

Právě kniha A. Doležalové ${ }^{3}$ A History of Czech Economic Thought, kterou vydalo nakladatelství Routledge v Londýně, je aktuálním př́spěvkem k poznání historie ČEM. Publikace je součástí tematické řady The Routledge History of Economic Thought, jež postupně představuje jednotlivé a dosud převážně velké ekonomické školy. Autorka se v knize systematicky zabývá dějinami ČEM od pozdního středověku až do současnosti, a to v teritoriálním vymezení, resp. zaměřuje se na úvahy autorů, kteří ovlivnili vývoj myšlení o ekonomických otázkách na území dnešní České republiky. Sleduje metodologický vývoj a vztah mezi ekonomií a politikou. Představuje nejvýznamnější postavy v oboru, ale i ty, na něž se téměř zapomnělo, včetně ekonomů, kteří ve druhé polovině dvacátého století působili v exilu nebo disentu. Zkoumá ideologické spory, generační konflikty i vzájemné vazby a šíření myšlenek a zařazuje české ekonomické myšlení do širšího evropského kontextu. Autorka sleduje tři základní myšlenky. 1. Zaměřuje se na analýzu metodologického vývoje a témata, která jsou zásadní pro pochopení ČEM, a zvažuje jeho př́nos v kontextu evropské tradice ekonomického myšlení. 2. Zvažuje, pod kterými mezinárodními vlivy se ČEM utvářelo a zároveň čím ovlivnilo evropské ekonomické myšlení. 3. Jak se ČEM vyvíjelo v kontextu politických změn v českých dějinách.

Kniha obsahuje kromě čtyř základních kapitol, jež jsou řazeny chronologicky bez přesné časové definice, úvod, poděkování a krátký epilog. Text je doplněn obsáhlým seznamem literatury a orientaci usnadňuje rejstř́ik. Každá kapitola zachycuje vždy: nejprve základní ekonomicko-politický kontext; hlavní rysy ekonomického myšlení; nejvýznamnější osobnosti a trendy; výuku ekonomie; způsob šiření ekonomických myšlenek v širší společnosti a dobový způsob přemýšlení o ekonomických otázkách. V těchto subkapitolách autorka za prvé odkrývá povahu ČEM a jeho vymezení jako vědy - ČEM chápe ekonomii jako komplexní vědu, jejíž podstatou je porozumění ekonomickým faktům a náprava sociálních podmínek. Za druhé zkoumá kognitivní schopnosti ekonomie a její roli ve společnosti, přičemž ekonomii chápe jako společenskou vědu se zásadním vlivem na společnost. A konečně za třetí vysvětluje postavení ekonomie mezi teorií a politikou a objasňuje její politizaci.

2 https://www.bibliothecaeconomica.cz/

3 Ekonomka, historička a filozofka, působí na Fakultě sociálních věd Univerzity Karlovy a Robinson College, v Cambridgi. Zabývá se hospodářskými dějinami a dějinami českého ekonomického myšlení, fiskální politikou, nacionalismem ve vztahu k národohospodářské politice, politickým stranictvím (agrární strana), altruismem a filantropií (https://ies.fsv.cuni.cz/sci/ publication/user/id/443/lang/cs) 
První kapitola Mezi vírou a svobodou: křestanské kořeny českého ekonomického myšleni je zaměřena na identifikaci prvků ekonomického myšlení ve spisech českých středověkých a raných moderních myslitelů. Zejména to byli čeští reformátoři církve, kteří se zamýšleli nad vztahem soukromého a společného majetku, prozřetelností a lidským chováním, sociální spravedlností, milosrdenstvím a charitou. Historický kontext odpovídá zhruba období od př́chodu Cyrila a Metoděje na Moravu v roce 863 po období po Bílé hoře (1620), sleduje význam panovníků a sílu šlechty i církve, vliv husitského hnutí i následnou rekatolizaci. Vzhledem k tomu, že jedinou vědou středověku byla teologie, byly i ekonomické problémy, resp. otázky svobody, rovnosti, spravedlivých cen a uspořádání společnosti nahlíženy z pohledu křest’anství. Na Filozofické fakultě se studovala díla Aristotelova a jejich interpretace Tomášem Aquinským nebo Albertem Velikým. Základem studia ekonomie byla Nichomachova etika, Politika a pseudoaristotelská Oeconomica.

Zvláštní pozornost $\mathrm{v}$ této kapitole věnuje autorka ekonomické problematice $\mathrm{v}$ učení Jana Husa a Jana Amose Komenského. Hus se při svém hledání pravdy pohyboval po liniích velkých scholastických realistů a na základě víry. Jeho ekonomické názory lze číst pouze mezi řádky. Ekonomie je pro něj skutečně přirozenou součástí porozumění světu a chování jednotlivce v něm. Je součástí zájmu o každodenní život a má zásadní důsledky pro věčný život. Jasně ekonomická linie se projevuje v Husově pojetí soukromého vlastnictví, almužny, chudoby a bohatství, práce a spravedlivé mzdy nebo peněz. Blaženosti lze dosáhnout pouze cestou ctnosti, tj. životem podle Písma. Jan Amos Komenský, stejně jako Jan Hus, byl teologem, jeho ekonomické úvahy najdeme implicitně v minimálním počtu textů. Jeho snahy napravovat lidské záležitosti byly pevně zakořeněny v Písmu. Nejdůležitějším odkazem je důraz na svobodu lidské vůle a vzdělání, jež považuje za předpoklad jakékoli sociální změny. Kořenem všeho zla je nevědomost a negramotnost. Komenský respektuje sociální stratifikaci společnosti, soukromé vlastnictví a svobodu volby každého jednotlivce při každé ekonomické akci. Připouští, že nespravedlivé chování bohatých prostřednictvím daní, poplatků a lichvy je zdrojem chudoby. Zároveň považuje bohatství za Boží odměnu za pracovitost. Vzdělání je klíčovým prostředkem pro zušlechtování lidstva. Společnosti přiřazuje sedm hlavních stavů, z nichž nejvyšší jsou filozofové, teologové a učitelé. Hned za ně staví obchodníky, protože cesta k prosperitě je ekonomická. Všichni přispívají k sociální blaženosti prostřednictvím veřejné i soukromé služby. Blaho národa má přednost před individuálním. Sociální péče je cílem lidské společnosti a měla by být nejvyšším zákonem. Odkaz Komenského je v ČEM skrytě př́tomen např. v díle Františka L. Chleborada. Komenského logika „štěstí jednotlivce a národa je harmonicky propojeno" se objevuje i u Johanna J. Bechera.

Druhá kapitola Mezi posláním a povoláním: od osvícenství $k$ institucionalizaci (1648-1882) se zabývá obdobím od druhé poloviny 17. století do konce 19. století. 
Po třicetileté válce byly Čechy součástí habsburské monarchie s expandující manoriální ekonomikou a druhým nevolnictvím. Šíření nových ekonomických myšlenek brzdily ekonomické zájmy šlechty a dvojaký vliv jezuitů. Kapitola zpochybňuje obvyklý názor, že $\mathrm{v}$ té době byla ekonomie chápána jako praktická disciplína, jejíž účelem bylo primárně optimalizovat státní správu. Jsou zde naznačeny interdisciplinární kořeny ekonomického myšlení (existují čtyři zdroje: aristotelovská věda, poznatky př́rodních věd, empirické poznání habsburské monarchie a odkaz české reformace). Podle autorky samotný vznik ekonomie jako oblasti vědy byl v Čechách výsledkem osvícenských myšlenek, jež se šírily mezi intelektuály i vládnoucími strukturami. Pozornost v ekonomických diskusích se soustředila především na otázky aplikovatelnosti principů merkantilismu a liberalismu v českém prostředí a podpory zemědělství a vznikajícího průmyslu. Kapitola se soustředí na klíčové osobnosti rakouského kameralismu, Františka Ladislava Riegera, Bernarda Bolzana a Františka Ladislava Chleborada.

Kameralisté chápali společnost jako propojený celek. Snažili se podzvednout obyvatelstvo z chudoby a nabídli nové interpretace státní správy (spravedlivý ekonomický rád, zrušení nevolnictví, zakládání škol, inovace apod.). Základ ekonomiky tvořilo zemědělství jako zdroj výroby a obchodu; dělbu práce považovali za základní podmínku bohatství společnosti. Byly formulovány první fiskální a měnové teorie o rozdělování bohatství ve společnosti. Autorka přibližuje známé kameralisty, jako jsou J. J. Becher, P.W. von Hornigk, W. von Schröder nebo J. Sonnenfels, i neznámé žáky P. W. Hornigka a J. Sonnenfelse. Jsou jimi Josef Ignác Butschek, rytî́r z Heraltic, Leopold Ludwig Schulz von Strasznitzki a Václav Gustav Kopetz, jež byli prvními učiteli kameralismu v zemích České koruny. Kopetz zvažoval řadu návrhů pro zlepšení stavu zemědělství, rozdělení půdy a odstranění roboty. Jeho ideálem byla uzavřená, soběstačná ekonomika, jejíž základem je zemědělství. Byl kritikem Sonnenfelsovy práce a do českého akademického prostředí zavedl práce A. Smithe a německou historickou školu. Kopetzovi současníci Jiří František August, hrabě Buquoy, a rytî́ Alois Leopold Lexa z Aehrenthalu byli průkopníky formalizace a matematizace v ekonomii. $\mathrm{V}$ textech Buquoye lze pozorovat úroveň ekonomického myšlení v Čechách v první polovině 19. století. Vyšel z kritické analýzy Smithe, ekonomii vnímal jako teoretickou a technickou vědu. Uvědomoval si limity využití kvantitativních metod v ekonomii. Buquoy přidává ke Smithově teorii Becherovy požadavky na všeobecný blahobyt ve všech sociálních trrídách. A. Lexa kromě využití formalizace vytvářel vlastní ekonomické pojmy v češtině.

Bolzano a Chleborad byli původními sociálními mysliteli a prvními propagátory koncepcí spolupráce (družstevnictví) v českých zemích. Ve svých ekonomických úvahách Bolzano propojil biblickou interpretaci s nejnovějšími směry sociálního myšlení a svými originálními myšlenkami. Jeho koncept nové společnosti měl formou reforem překonat zaostalý feudalismus, vzájemnou nesnášenlivost a nespravedlivé rozdělení majetku. 
Vlastnictví považuje za zásadní ekonomickou kategorii fungování společnosti. Zabývá se rolí státu a státního rozpočtu. Nejlepší cestou k nové společnosti je vzdělání. Soustava národního hospodářství politického (1869) Františka Ladislava Chleborada je první komplexní interpretací ekonomie v češtině. Kombinuje ekonomickou analýzu s prírodními vědami, etikou, právní vědou, politologií, filozofí, historií, statistikami a finanční vědou a dalšími vědami. Chleborad zde nabízí návrh vlastní ekonomické struktury, v níž je soukromé vlastnictví a svoboda jednotlivců harmonicky spojeno se zájmy celku. Ekonomii chápe jako syntetickou, etickou a normativní i teologickou vědu. Klíčový analytickým pojmem je blahobyt. Počátkem ekonomického cyklu je lidský duch včetně morálky. Chleboradův koncept, který vycházel ze subjektivní teorie hodnoty a lidského kapitálu, autorka nazývá homo economicus ethicus.

Samostatnou subkapitolu tvoří jednak analýza vzniku a vývoje ekonomického školství v zemích České koruny od kameralistických návrhů na zřízení praktických škol, posílení praktických předmětů na základních školách, zdokonalení učebních osnov gymnázií a zakládání obchodních akademií až po zavedení vysokoškolského ekonomického vzdělávání v češtině. Dále analýza způsobů šiření ekonomických idejí v širší veřejnosti. České národní obrození propagovalo vzdělávání jako prostředek podpory moderního ekonomického rozvoje.

Třetí kapitola Mezi ekonomií a politikou: od slavných začátkủ k hořkým koncům (1882-1948) je nejrozsáhlejší. Institucionalizace ekonomie je zde analyzována na pozadí vývoje habsburské monarchie a samostatného Československa přes období protektorátu až $\mathrm{k}$ převzetí moci komunisty. $\mathrm{V}$ tomto období se čeští ekonomové zajímali o různé proudy současného ekonomického myšlení. Na začátku se stala ústřední otázkou jejich zájmu sociální otázka, vývoj kapitalismu a rozdělení bohatství mezi monarchií a českou zemí. Autorka přestavuje Albína Bráfa, zakladatele metodologie ekonomie, který pomohl dokončit českou ekonomickou terminologii a propojil ekonomii s praktickými problémy české společnosti. Ovlivnil významně další vývoj ČEM i výuku ekonomie. V knize je analyzováno, jak on sám byl ovlivněn liberalismem, německou historickou školou a K. Mengerem. Bráfův současník Josef Kaizl vyvinul novou fiskální teorii vycházející z konceptu organického složení státní ekonomiky a spočívající ve formální a obsahové analýze potřeb státu a nákladů nezbytných $\mathrm{k}$ jejich uspokojení. Bráfio žák František Čuhel v souladu s rakouskou školou uplatnil nové pojetí studia lidského chování. Zavedl koncept ordinální užitečnosti, která ovlivnila evropské ekonomické myšlení (Čuhelova-Misesova ordinální užitečnost). Z meziválečných ekonomů je pozornost věnována Bráfovým žákům - osobnosti Karla Engliše, pro kterého byla systémovým základem pro tvorbu ekonomické teorie noetika. Východiskem pro formulaci logických pravidel chování ekonomických subjektů a celé jeho ekonomické teorie (teorie hodnoty, teorie směny a ceny, teorie ekonomických 
řádů a teorie státní ekonomiky) mu byla teleologická metoda ${ }^{4}$. Další Bráfův student, Josef Macek, rozvinul liberální socialistický koncept ekonomie jako společenské vědy v duchu svého specifického pojetí socialismu, jež se vymyká současnému pojetí tohoto termínu. Ekonomie by měla objevit pravidelné souvislosti mezi ekonomickými jevy a zároveň pomoci reformovat společnost. Etika je nedílnou součástí ekonomie při volbě prostředků $\mathrm{k}$ dosažení sociálních cílů. Propagoval obrat ekonomie směrem $\mathrm{k}$ aktivní hospodářské politice.

Kapitola dále analyzuje počátky českého marxismu, kooperativních teorií (Samosprávy práce F. Modráčka a kooperativního socialismu J. Macka) i další součásti ČEM, jako byly laboretismus, problematika státního sektoru a státních podniků, krize a plánování. V subkapitole o výuce ekonomie je největší pozornost věnována výuce ekonomie na české části Karlo-Ferdinandovy univerzity a Vysoké škole obchodní, včetně její opakované transformace.

Čtvrtá kapitola Mezi teorií a ideologií: ekonomie jako politický nástroj (1948-1989) ukazuje, jak se ekonomické myšlení po roce 1948 dostalo pod vliv marxismu-leninismu, jenž se ztotožňoval s teorií socialistické revoluce a socialistické ekonomiky. Jediné seznámení s ekonomickými myšlenkami v mezinárodním měřítku bylo možné jen v rámci „kritiky“" nemarxistických ekonomických škol. Marxismus-leninismus se stal téměř výhradně jazykem ekonomie v Československu po dobu následujících 40 let. V souladu s marxistickým historickým materialismem mohla ekonomie sloužit jako způsob formulace teze týkající se historicky nezbytného vývoje od kapitalismu k socialismu. Ekonomické plánování se stalo hlavním tématem českého ekonomického myšlení. Diskuse o povaze socialismu byla zahájena v 60. letech 20. století. Ekonomové z generace, která získala vzdělání v marxisticko-leninské politické ekonomii, se této diskuse zúčastnili vůbec poprvé. Jejich práce však ukazuje, jak je nesprávné označit 40 let ekonomického myšlení v socialistickém Československu za marxisticko-leninského klišé.

Text analyzuje ekonomické myšlení v 50., 60., a 70. a 80. letech i jeho výuku na Vysoké škole ekonomické v Praze. Velký prostor je věnován teoretickým úvahám v době pražského jara. Mezi ekonomy, analýze jejichž díla je věnována specifická pozornost, najdeme vedle Josefa Goldmanna, Otu Šika a Miroslava Tomse, také poněkud překvapivě filozofa Karla Kosíka a jeho Dialektiku konkrétního. Jak autorka dokazuje, bez pochopení Kosíkova vlivu by zůstala část potenciálu českého marxistického myšlení skryta. Právě původní Kosíkova filozofie lidského jednání zpochybňuje používanou socialistickou realitu, ale také objektivní pravdu, podle níž je realita ideologicky rámována a v konečném důsledku vrací ekonomii do sféry společenských věd jako vědy o lidském jednání. 
Protože autorka se snaží zachytit, jak byl vývoj ekonomického myšlení ve 20. století ovlivněn zásahem totalitních režimů, které vedly ke třem vlnám emigrace z Československa - v letech 1938, 1948 a 1968, zařazuje do této kapitoly také subkapitolu o českém myšlení v exilu a v disentu. Tvrdí, že právě v exilu je možné sledovat silnější rysy kontinuity než v domácím českém ekonomickém myšlení. Významnými exilovými ekonomy byli J. V. Mládek (ředitel MMF) a A. Basch (spolupracoval se Světovou bankou). Někteří působili na amerických a kanadských univerzitách jako J. M. Novotný, J. Macek a J. Vaněk (přispěl k diskusi o Leontiefově paradoxu). Text zmiňuje aktivity Společnosti pro vědu a umění (zal. r. 1957 v New Yorku), spojené s podporou exulanti̊ ve výzkumu a především snahou vydat překlad hlavních děl Karla Engliše (v Československu zakázány r. 1970). Dalším domácím centrem šíření ekonomie byly semináře kolem V. Kadlece (samizdat Ekonomická revue a Ze zásuvky) a diskuse o nemarxistické samizdatové knize Zdislava Šulce.

Po sametové revoluci v roce 1989 byl význam českých národohospodářů rehabilitován. Ovšem vliv exulantů na hospodářskou reformu 90. let byl minimální (J. Švejnar v Centru ekonomického výzkumu CERGE). V českém prostředí nebyla akceptována ani Šikova koncepce třetí cesty, ani Vaňkova vize samosprávné demokratické ekonomiky.

Poslední část textu - epilog, nazvaný Nesnesitelná lehkost ekonomie, zachycuje ekonomické myšlení v období sametové revoluce a volbu transformačních strategií. Dochází k závěru, že transformační strategie byla výsledkem nikoli volné diskuse, jak by se očekávalo (Ekonomické fórum, 1989), ale politické volby v duchu Washingtonského konsenzus

Autorce se podařilo připravit velmi zdařilou knihu. Dosud žádná publikace se nezabývá dějinami českého ekonomického myšlení v tomto rozsahu a takto systematicky. Přibližuje základní principy ČEM, vzájemné vazby a prolínání myšlenek jednotlivých představitelů a dokládá, že je cennou součástí evropské tradice. Nelze než odkázat na slova autorky v úvodu knihy: „Bez ohledu na to, že tradice českého ekonomického myšlení byla z evropského pohledu vždy ve stínu německé a rakouské ekonomické analýzy, je zrejejmé, že se vzájemná inspirace mezi českým a evropským myšlením volně širíila. Evropské myšlení ovlivnila česká reformace. Na počátku 19. století byli čeští ekonomové mezi prvnimi, kteří přehodnotili využití matematiky v ekonomii; v pozdním 19. století Albín Bráf přispíval $k$ diskusi o metodě; počátkem 20. století ovlivnil František Čuhel Ludvika von Misese a jeho teorii užitečnosti; $v$ meziválečném obdobi byla v kontextu rakouské školy diskutována teleologická teorie lidského chováni Karla Engliše, která v 60. a 70. letech rezonovala zejména mezi českými ekonomy žijícimi v exilu ve Spojených státech. Po druhé světové válce přitahovaly myšlenky českých ekonomů ohledně ekonomického plánování

5 Strategie Mezinárodního měnového fondu a Světové banky na pomoc přechodovým ekonomikám. 
$v$ demokratické společnosti značný evropský zájem. Projekty reforem socialismu upoutaly mezinárodni pozornost na ČEM během pražského jara v 60. letech a poté znovu v 90. letech v souvislosti s prechodem ke kapitalismu. "

Domnívám se, že publikace, doplněná rozsáhlým poznámkovým aparátem a působivým seznamem zejména původní domácí, ale i zahraniční literatury, zaujme především odborníky z oblasti ekonomie i historie a stane se tak zdrojem inspirace pro další výzkum. Lze ji však vřele doporučit všem zájemcům o ekonomický vývoj naší společnosti. Zájem širší veřejnosti dokládá účast v soutěži společnosti Patria, která se uskutečnila v roce 2019 ve spolupráci s autorkou. Fakt, že publikace vyšla v zahraničním prestižním nakladatelství v rámci tematické řady představující ekonomické myšlení v jednotlivých zemích, považuji za mimořádnou př́ležitost přibližit ČEM zahraniční odborné veřejnosti. Zároveň nelze pochybovat, že by pro rozvoj domácí ekonomické vědy bylo prínosem, pokud by tento text byl dostupný česky. Knihu bych ráda doporučila rovněž pro účely výuky na vysokých školách ekonomického zaměření. Zde souhlasím s autorkou, že naše současné ekonomické školství cílí především na obchod a management a ekonomická teorie a dějiny ekonomického myšlení jsou pouhou „Popelkou“. 